\title{
Anti-Corruption Review in global health
}

Farkhod Fazilov, PhD, Senior lecturer of Criminal law, criminology and fight against corruption Department of the Tashkent State University of Law, Uzbekistan, Tashkent fazilov.farhod@gmail.com ORCID: https://orcid.org/0000-0001-8603-1948

\begin{abstract}
This article has attempted to identify key priority areas that urgently need global attention to advance the fight against corruption in the health sector. The problem has become even more obvious and relevant in the context of the coronavirus pandemic. Over two-thirds of countries are considered endemically corrupt according to Transparency International. Corruption can be seen in all societies. It is estimated that the world spends more than US\$7 trillion on health services, and that at least $10-25 \%$ of global spending is lost directly through corruption, representing hundreds of billions of dollars lost each year.
\end{abstract}

Keywords: Corruption, health care, pandemic, prevention, global Received: 08.12.2020 Accepted: 11.01 .2021 Published: 06.02.2021

\section{Introduction}

Corruption can be seen in all societies. When corruption infiltrates the health sector, it can be particularly destructive, threatening economic development, international security and public health. At the same time, the multifaceted and complex nature of corruption in the health sector makes it extremely difficult to combat it, despite the huge costs that are estimated at billions of dollars.

Everyone shall have the right to receive skilled medical care in Uzbekistan. Citizens of the Republic of Uzbekistan have the inalienable right to health care.

The Law on health protection of 1996 confirmed the right of citizens to health care. This right applies to all health services, including delivery, antenatal and neonatal care, paediatric services, immunization, family planning, outpatient services and specialized services. The state guarantees health protection irrespective of age, race, gender, ethnicity, religion, social status and beliefs.

The State system for health administration has been improved. International medical and health regulations drawn up by WHO to respond to the global spread of diseases have been introduced.

Anti-corruption is one of the important issues of state policy against crime in the Republic of Uzbekistan and in other countries. This strong political will was reflected in the adoption of fundamental decisions on the accession of the Republic of Uzbekistan to the UN Convention against Corruption, the Istanbul Action Plan of the Anti-Corruption Network of the Organization for Economic Cooperation and Development, joining the Egmont Group, the Eurasian Group on Combating Money Laundering and financing of terrorism (with the subsequent ratification of the EAG Agreement).

In the Republic of Uzbekistan, anti-corruption issues are provided for in the Law of the Republic of Uzbekistan dated July 30, 2018 No. LRU-489 "On Combating Corruption". The legislative definition of corruption in Uzbekistan is also interesting. Thus, the Law "On Combating Corruption" of the Republic of Uzbekistan defines the concept of "corruption" as the illegal use by a person of his/her official or official position in order to obtain material or non-material benefits in personal interests or in the interests of other persons, as well as illegal provision of such benefits (2018).

The Criminal Code of the Republic of Uzbekistan, although it does not provide for the concept of corruption crimes, contains responsibility for crimes that can be recognized as such - theft by embezzlement or embezzlement (Article 167), malfeasance, including bribery (Articles 205-214).

To date, work is underway to prepare a new version of the draft Criminal Code of the Republic of Uzbekistan. Thus, the Concept of improving the criminal and criminal procedural legislation of the Republic of Uzbekistan, approved by the decree of the President of the Republic of Uzbekistan dated May 14, 2018, No. PD-3723, the main tasks are the inventory of criminal legislation for its unification and harmonization with international standards, as well as the continuation of the course strict criminal policy against persons guilty of committing corruption crimes.

The fight against corruption in all spheres of society has been identified as one of the main priorities of the Development Strategy of Uzbekistan for 2017-2021.

Under the chairmanship of the President of the Republic of Uzbekistan Shavkat Mirziyoyev, on June 30 of this year, a video conference was held on issues of ensuring justice and combating corruption, where the head of state pointed out that now the specialized committees in the parliament of Uzbekistan 
will conduct a rating of justice and the corruption situation in each region of the country, and the results of each half-year - to conduct parliamentary hearings and inspections.

On June 29, the head of state signed a decree "On additional measures to improve the anticorruption system in the Republic of Uzbekistan". In this connection, the Anti-Corruption Agency has been created, which is subordinate to the President and reports to the parliament, and also develops and implements state policy in the field of preventing and combating corruption.

\section{Objectives}

1) the study of corruption in health care;

2) determining the influence of corruption on the fight against epidemics and crime;

3) an attempt to develop measures to prevent corruption practices in health care.

\section{Materials and Method}

In the course of the study, methods such as historical, systemic-structural, comparative-legal, logical, specifically sociological, complex research of scientific sources, induction and deduction, analysis of statistical data were applied.

\section{Results}

Corruption has serious implications for access, quality, equity, efficiency and effectiveness of health services and impedes the long-term goal of universal health coverage.

In 1996, former World Bank President James Wolfensohn delivered a groundbreaking speech calling for international action and attention to tackle what he called "the cancer of corruption" (1996).

Decades later, this portrayal of corruption as a devastating disease seems appropriate, as corruption related to health is now a multifaceted, multi-jurisdictional and multi-billion dollar phenomenon that threatens the future progress of global health (Mackey TK Liang BA, 2012). So corruption in health can range from petty corruption to high-level national or even multinational, corruption.

"... Our people suffer from corruption ... as an example, we can cite the healthcare and other social spheres. In particular, at the moment, in a pandemic, some officials of the centers of sanitary and epidemiological well-being, instead of selfless service to the people, have taken the path of crime.

According to the General Prosecutor's Office of the Republic of Uzbekistan, budget funds in the amount of 917.8 million have been plundered in the Kashkadarya region, 509.8 million in the Navoi region, 248.9 million in the Namangan region, 202.5 million in the Bukhara region, and in the Andijan region - 159.3 million soums" (2020).

Like cancer, there are several types of corruption related to health, ranging from "petty" corruption, such as medical absenteeism, to "systematic" corruption involving multinational companies involved in widespread fraud and abuse in the health sector, and "large-scale" corruption at high levels).

The motivation of various actors, including officials, private companies and organized crime communities to engage in health-related corruption, should not come as a surprise: the health sector is one of the largest segments of the global economy, accounting for nearly $10 \%$ of the world according to the World Bank (GDP) (2019).

Of the trillions of dollars spent annually on healthcare globally, most is spent on large government contracts for drugs, equipment, and hospital construction) (2012).However, estimates show that $10-25 \%$ of global public procurement spending is "wasted" by corruption) (2006).

We live in an era of epidemics and potential pandemics. It is enough just to list some of the main threats of the last few years: the Zika, Ebola, MERS epidemics, and of course the coronavirus pandemic.

In addition to the morbidity and mortality they cause, these events are often associated with huge economic and social losses and therefore are increasingly viewed not only as public health problems, but also as national and global security problems.

Corrupt practices not only affect individual patients and their places of origin, but in the event of new diseases, they can potentially have wider, even global, consequences for human health and wellbeing.

Preventing an outbreak is primarily the best possible health security outcome, but this requires an effective public health system with good governance and oversight. Unfortunately, many health systems struggle to provide access and high quality services, often due to various corrupt practices (Margot I Witvliet, Anton E Kunst, Onyebuchi A Arah, Karien Stronks, 2013). 


\section{Conclusion}

Covid-19 has unleashed state corruption on a grand scale, and it is harmful to public health (Geoghegan P., 2020). Politicians and industry are responsible for this opportunistic embezzlement. So too are scientists and health experts. The pandemic has revealed how the medical-political complex can be manipulated in an emergency-a time when it is even more important to safeguard science (Kamran Abbasi, 2020).

The health sector is an attractive sector for corruption. These billions lost to corruption exceed WHO's estimations of the amount needed annually to fill the gap in assuring universal health coverage globally by 2030 ( Jones B, Jing A., 2011).

What measures can help in the global fight against corruption in the health sector? In our opinion, it is necessary to implement such measures as: corruption.

1. Approval in the country and at the international level of the concept of "zero" tolerance for

2. Creating conditions for the publication of open data on corruption in the health sector, both nationally and globally.

3. Increasing transparency and disclosure of financial information, for example, on transactions in the health sector, procurement systems in the health sector.

4. Strengthening the partnership between the state and civil society in combating corruption in this area.

COVID-19 crisis therefore provides an opportunity for all countries to strengthen anti-corruption and integrity as part of improving governance effectiveness - a crucial factor in pandemic preparedness. As countries now revisit their pandemic response plans and policies, it is vitally important that they integrate anti-corruption as an essential part of this. It must not be added simply as an ad hoc measure (2020).

\section{References}

Geoghegan P. Cronyism and clientelism. London Review of Books 2020 Nov 5. https://www.lrb.co.uk/thepaper/v42/n21/peter-geoghegan/cronyism-and-clientelism

http://data.worldbank.org/indicator/SH.XPD.TOTL.ZS

http://documents.worldbank.org/curated/en/243871468141893629

http://www.who.int/mediacentre/factsheets/fs319/en/

https://kun.uz/ru/news/2020/08/21/chto-obsujdalos-na-pervom-zasedanii-natsionalnogo-soveta-po-

borbe-s-korrupsiyey

https://lex.uz/docs/3088013

https://www.u4.no/publications/anti-corruption-in-covid-19-preparedness-and-response

Jones B, Jing A. Prevention not cure in tackling health-care fraud. Bull World Health Organ 2011; 89: 85859.

Kamran Abbasi Covid-19: politicisation, "corruption," and suppression of science BMJ 2020;371:m4425

Mackey TK Liang BA Combating healthcare corruption and fraud with improved global health governance. BMC Int Health Hum Rights. 2012; 12: 23

Margot I Witvliet, Anton E Kunst, Onyebuchi A Arah, Karien Stronks Sick regimes and sick people: a multilevel investigation of the population health consequences of perceived national corruption Trop Med Int Health. 2013. 18 (10): 1240-7.

Transparency International. Global Corruption Report 2006: Corruption and Health. London and Ann Arbor: Pluto Press and Transparency International; 2006

Fayziyev Shokhrud Farmonovich Medical law and features of legal relations arising in the provision of medical services. International journal of pharmaceutical research Volume 11, Issue 3, July - Sept, 2019 P. 1197-1200

doi:10.31838/ijpr/2019.11.03.088

http://www.ijpronline.com/ViewArticleDetail.aspx?ID=11016

Bryanskaya Elena, Fayziev Shokhrud, Altunina Anna, Matiukha Alena Topical Issues of an Expert Report in the Process of Proving in a Criminal Examination. International Journal of Engineering and Advanced Technology (IJEAT) ISSN: 2249 - 8958, Volume-9 Issue-1, October 2019 5345-5349 DOI: 10.35940/ijeat.A2946.109119

content/uploads/papers/v9i1/A2946109119.pdf

https://www.ijeat.org/wp-

Fayziev Shokhrud (2019) Legal Aspects of Transplantology in the Republic of Uzbekistan. Systematic Reviews in Pharmacy, ISSN: 0976-2779, Vol: 10, Issue: 2, Page: 44-47 doi:10.5530/srp.2019.2.08 http://www.sysrevpharm.org//fulltext/196-1575419211.pdf?1586863081 
Tulaganova, G. Some issues of observance of international legal norms of fight against legalization of criminal incomes in the Republic of Uzbekistan Journal of Advanced Research in Dynamical and Control Systems 12(2 Special Issue), c. 143-155

Bazarova D. Some problems of counteracting crimes related to laundering of illegal proceeds in Uzbekistan Journal of Advanced Research in Dynamical and Control Systems. Volume 11, Issue 7, 2019, Pages 873-885 